\title{
THE FRESH AND SALT WATER DISTRIBUTION IN THE UNCONFINED AQUIFER IN NORTHERN FLANDERS
}

\author{
W. DE BREUCK, E. BEEUWSAERT \& K. WALRAEVENS \\ University of Ghent, Laboratory for Applied Geology and Hydrogeology, \\ Krijgslaan 281-S8, 9000 Gent, Belgium
}

\begin{abstract}
The interface between fresh and salt water in the unconfined aquifer of Zealand Flanders (The Netherlands) and the adjacent area in Belgium has been mapped by means of a resistivity survey controlled by many well observations. The interface corresponds with an interpreted formation resistivity equal to or less than $6 \Omega \mathrm{m}$. The distribution pattern of fresh and salt water is tightly linked to the geological evolution of the area. Especially the latest phase of the Dunkirk transgression and the historical inundations have had a thorough influence
\end{abstract}

\section{INTRODUCTION}

Zealand Flanders is the part of the province of Zealand (The Netherlands) located on the west bank of the river Scheldt. It is a flat polder area, which to the west extends into the coastal area of Belgium. The Holocene transgressions and historical inundations have caused the salinization of the unconfined aquifer. The reclamation of the area has resulted in a partial freshening of the aquifer. The natural as well as the artificial drainage have both influenced the present distribution pattern of fresh and salt water. This dynamic equilibrium can be easily upset by a lowering of the water table in a groundwater catchment or a lasting change of the level in the drainage ditches. The result is a salinization of the wells or worse a loss of agricultural land.

The intricate pattern of the fresh/salt-water interface is very difficult to assess by borings alone, not only because of the excessive costs but mainly because of the inaccessibility of many parts of the area. A geoelectrical survey was conducted in 1974-1975 and was updated in recent years. More than 700 electric soundings, mainly in Wenner array, were made in Zealand Flanders and in the adjacent polders on Belgian soil. At the request of the authorities of Zealand a map of the fresh/salt-water interface was established. The interface was defined at the interpreted formation resistivity dropping to or below $6 \Omega \mathrm{m}$. The map has been tested at many locations where wells were available to make groundwater analyses. The interface was always found within $1 \mathrm{~m}$ of the one located by the resistivity survey.

\section{GEOLOGY}

The substratum of the upper unconfined aquifer, mainly consisting of Quaternary sandy sediments, is formed by Tertiary deposits, ranging, from west to east, from Eocene Bartonian clay to Oligocene Rupelian clay. In between, Oligocene sandy deposits are a part of the unconfined 
reservoir. In some areas the Tertiary substratum has been deeply eroded in later periods, especially in Pleistocene times. During the latter, fluvioglacial and marine sediments have been deposited. These are mainly sandy. They attain a thickness from $10 \mathrm{~m}$ at the Belgian border to more than $40 \mathrm{~m}$ at the Scheldt river bank. The top layers are composed of Holocene deposits of the Dunkirk transgressions (fig. 1). During these transgression phases, deep creeks have been eroded into the Pleistocene deposits and the peat layer that had formed on top. Some of these creeks were cut right through the Pleistocene into the Tertiary substratum. These creeks later were filled mainly by sandy material, while outside the creeks, finer silty and clayey sediment was deposited on top of the peat or Pleistocene sands.

The reclamation and the drainage of the polders have provoked in some areas a differential settlement of the top layers and an inversion of the relief. The clay-covered peat layers were compacted far more than the sand in the creeks, leaving the latter to become the higher grounds.

\section{FRESH/SALT-WATER DISTRIBUTION}

The present pattern of the isopachs of the fresh/salt-water interface has evolved during the latest centuries in a very slow manner, due to the extremely slow movement of the groundwater, especially in the deeper part of the aquifer. The Dunkirk II transgression covered the northern part of the area (fig. 1), creating a landscape which after inversion consisted of lowlying clay-covered peat areas and higher creek ridges. The latter also had a higher permeability, thus facilitating the infiltration of fresh rain water after the regression of the sea. A fresh-water lens developed in the creek ridges, while the salt water was not flushed under the low-lying peaty areas. The Dunkirk Illa transgression only covered a small part in the west and in the east, but during the Dunkirk IIIb transgression (fig. 2) the sea penetrated deeply into the land, cutting very deep creeks, which later were filled once again by sandy deposits. Later inundations due to storm and very high tides locally influenced the fresh/salt-water distribution. In the sixteenth and seventeenth centuries, during the religious wars, and even in the eighteenth century (fig. 2), inundations were provoked bringing salt water into the area for prolonged periods. The present distribution is thus intensely linked to the recent history and is more complicated than the pattern in the Belgian coastal area, due to the action of man since the reclamation of the area.

\section{ACKNOWLEDGEMENT}

The geophysical survey originally started with the support of the Belgian National Fund for Scientific Research and was completed with the support of the Province of Zealand.

\section{REFERENCES}

Brand, K.J.J. (1993). De ontwikkeling van het polderlandschap in de Vier Ambachten en omringend gebied. In: Over de Vier Ambachten. (De Kraker A.M.J., Van Royen H. \& De Smet M.E.E., eds.), 41-60. Kloosterzande: Duerinck.

De Breuck, W., De Moor, G., Maréchal, R. \& Tavernier, R. (1974). Depth of the interface between salt and fresh water in the unconfined aquifer of the Belgian Coastal Area (19631973). Map at 1:100 000. In: Hydrogeology of Salt Water Intrusion. A Selection of SWIM Papers. (De Breuck W., ed.). Hannover: Heinz Heise (International Contributions to Hydrology (Castany G., Groba E. \& Romijn E., eds.), vol. 11, 1991).

De Breuck, W. \& Vermoortel, Y. (1993). Geohydrologisch onderzoek. Project Waterspil, 37 
p. Ghent: University - Laboratory for Applied Geology and Hydrogeology (internal report). Van Overmeeren, R.A. (1987). Elektromagnetisch en geo-elektrisch onderzoek ZeeuwsVlaanderen, 96 p. Delft: Dienst Grondwaterverkenning TNO (report).

Van Rummelen, F.F.F.E. (1977). Geologische kaart van Nederland 1:50 000. Bladen Zeeuwsch-Vlaanderen West en Oost, 79 p. Haarlem: Rijks Geologische Dienst.

Walraevens, K., Martens, K. \& De Breuck, W. Salt/fresh-water distribution in the polder area near Axel (Zealand Flanders). In: Proceedings SWIM 13, Cagliari (in press).

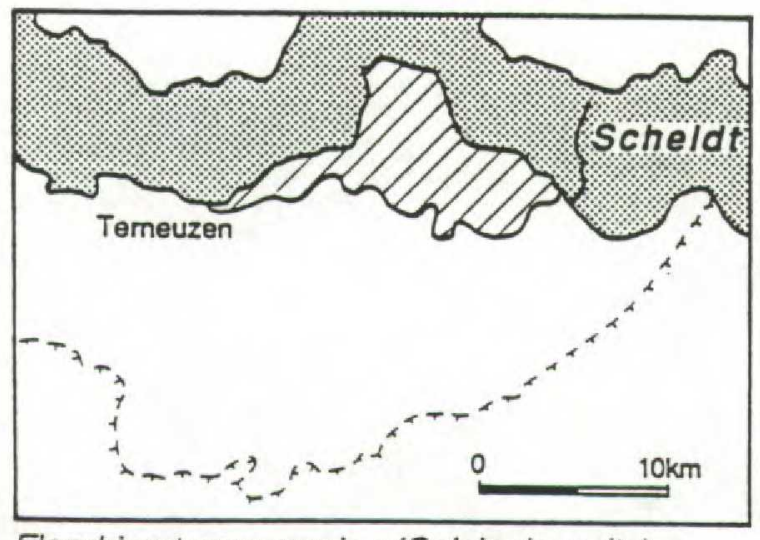

Flandrian transgression (Calais deposits)
Fig. 1. Hoiocene transgressions.

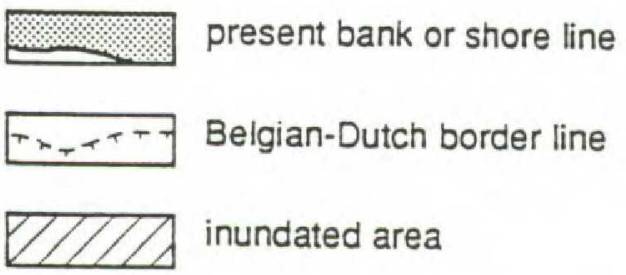

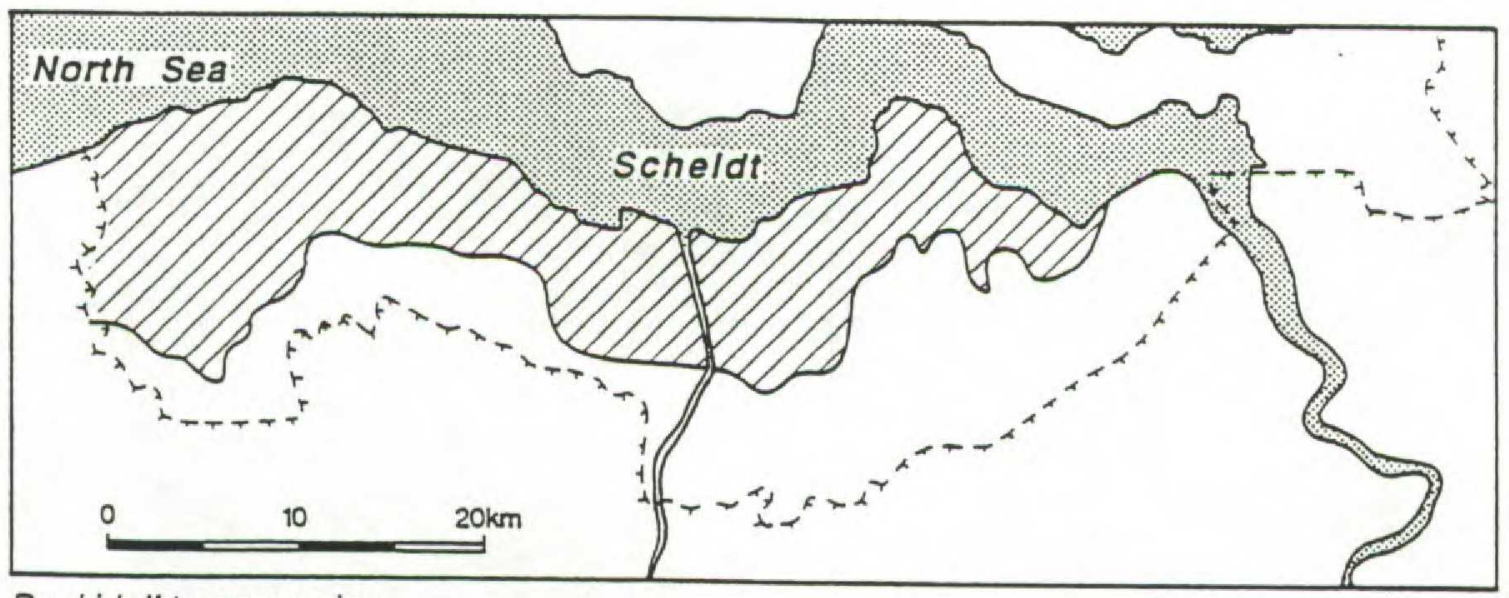

Dunkirk II transgression

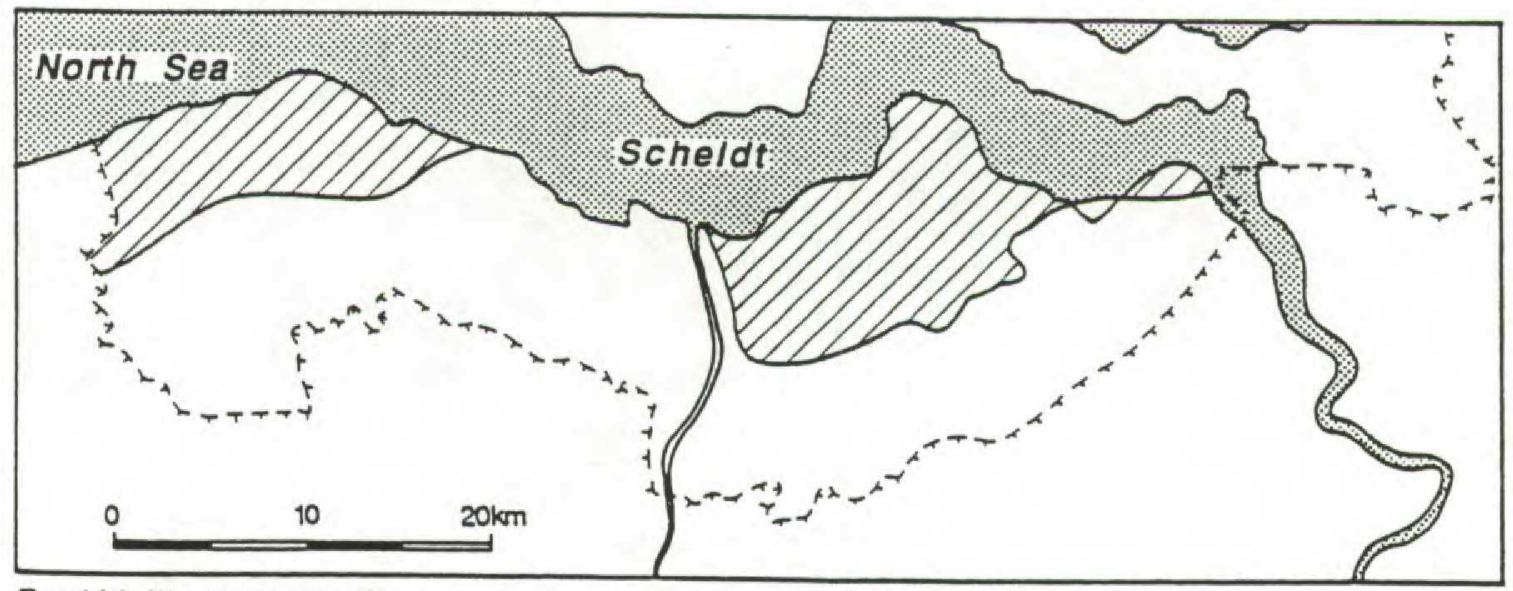

Dunkirk Illa transgression 

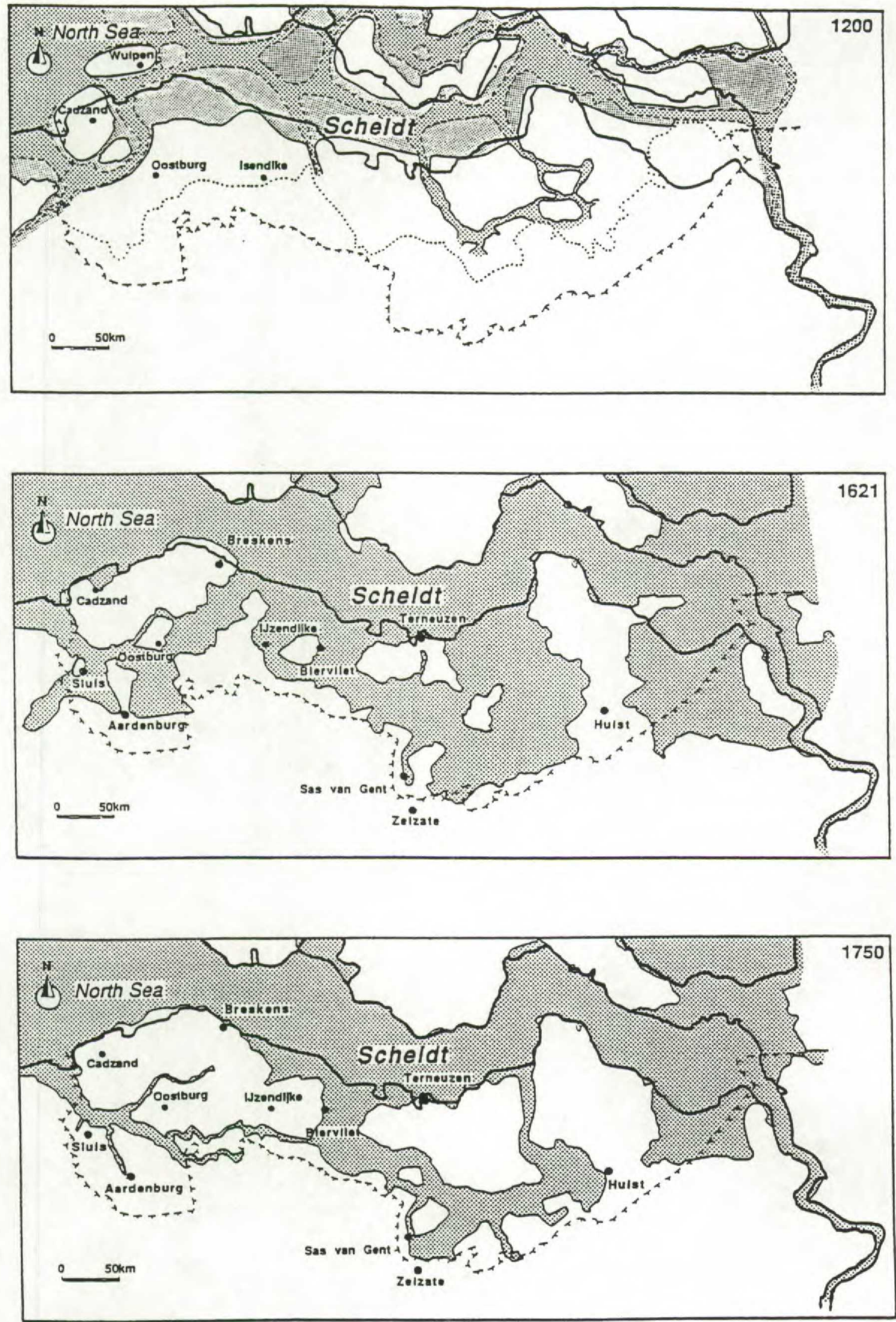

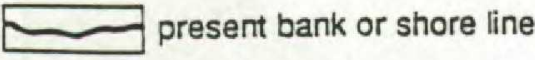

Brar+T Belgian-Dutch border line

border between clay and peat cover

Fig. 2. Inundations in historical time. 